\title{
Analisis Permintaan Pasar Telur Ayam Di Provinsi Sumatera Barat
}

\author{
Jum'atri Yusri, Andri dan E. Syahputra
}

Fakultas Peternakan Universitas Andalas Padang

\begin{abstract}
The research was objected to study the market demand on egg in West Sumatra in retain to several defined factors, i.e.; population number, people income, price of egg, broiler meat, beef meat, fish, rice and wheat flour. Secondary data were collected from 19852004 and statistically analyzed by wsing econometrics approach. Results showed that market demand of chicken egg in Sumatra Barat was significantly affected by the price of the egg and broiler meat and beef meat. The increase of population and their income gave no significant effect on egg demand.
\end{abstract}

Key words : chicken egg marketing.

\section{Pendahuluan}

Diprediksi potensi pasar untuk agribisnis peternakan masih besar dimasa yang akan datang, karena dari tahun ke tahun tingkat konsumsi masyarakat Sumatera Barat terhadap komoditi ternak terus mengalami peningkatan. sementara tingkat konsumsi sumber protein hewani asal ternak penduduk Sumatera Barat pada tahun 2004, baru mencapai 5,427 gram/kap/hari, sedangkan tingkat konsumsi yang disarankan Widya Karya Pangan dan Gizi tahun 1998 sebesar $6 \mathrm{gram} / \mathrm{kap} / \mathrm{hari}$.

Dari ketiga sumber protein hewani asal ternak (daging, telur, susu), telur ayam ras memberikan peranan yang paling besar terhadap penyediaan sumber protein hewani penduduk Sumatera Barat dimana dari semua jenis komoditi ternak, tingkat konsumsi yang paling besar terdapat pada telur ayam ras $(25,78 \%)$. Tapi jika dilihat dari laju pertumbuhan konsumsi masyarakat sclama periode 2002 - 2005, laju pertumbuhan konsumsi telur ayam menunjukkan pertumbuhan yang paling rendah yaitu $0,39 \%$, sementara untuk daging dan susu berturut-turut $6,35 \%$ dan 2,39\% (Dinas Peternakan Propinsi Sumatera Barat, 2005).

Dalam rangka memprediksi permintaan terhadap telur dimasa yang akan datang, diperlukan informasi tentang perilaku permintaan pasar telur ayam ras meliputi variabelvariabel apa saja yang menentukan / mempengaruhi permintaan terhadap telur ayam ras serta bagaimana respon pasar apabila terjadi perubahan pada variabel-variabelyang mempengaruhi.

Adapun tujuan dari penelitian ini adalah: 1) Menganalisis variabelvariabel yang mempengaruhi permintaan pasar terhadap telur ayam ras di Propinsi Sumatera Barat, 2) mengetahui respon permintaan pasar telur ayam ras jika terjadi perubahan pada variabel - variabel yang 
mempengaruhinya berupa nilai elastisitas permintaan.

\section{Materi Dan Metode}

\section{Metoda Penelitian}

Penelitian ini memakai metoda studi pustaka. Analisis dilakukan dengan pendekatan ekonometrika yaitu suatu bidang ilmu yang merupakan gabungan dari ilmu ekonomi, matematika dan statistik untuk menganalisis teori ekonomi secara kuantitatif berdasarkan data empiris (Firdaus, 2004).

\section{Pembentukan Model}

Untuk mendapatkan tujuan dari penelitian ini, dibangun model permintaan pasar untuk telur ayam ras di propinsi Sumatera Barat dengan memakai data sekunder deret waktu dari tahun 1985 sampai dengan tahun 2004. Adapun variabel - variabel yang dimasukkan sebagai variabel yang mempengaruhi permintaan pasar terhadap telur ayam ras didasarkan kepada teori permintaan Dimana secara teoritis, permintaan terhadap suatu komoditas dipengaruhi oleh : (1) harga komoditas yang bersangkutan, 2) harga komoditas lain yang berhubungan dengan komoditas yang bersangkutan, 3) tingkat pendapatan, 4) jumlah penduduk, dan 5) selera.

Untuk menganalisis permintaan telur ayam ras pada penelitian ini, variabel selera dianggap sama atau tidak mengalami perubahan selama periode analisis, yang menjadi barang substitusi adalah barang-barang yang mempunyai fungsi / manfaat yang sama dengan telur ayam ras, yaitu sama-sama sebagai komoditas sumber protein hewani, sehingga diduga barang substitusi untuk telur ayam ras adalah : telur ayam buras, daging broiler, daging sapi, dan ikan. Sebagai sumber protein hewani, telur ayam ras berfungsi sebagai lauk dalam menu sehari-hari pada rumahtangga, dimana lauk dikonsumsi secara bersama-sama dengan nasi, sehingga nasi yang didekati dari beras merupakan barang komplemen untuk telur ayam ras. Disamping dikonsumsi untuk menu schari-hari, telur ayam ras juga dikonsumsi dalam bentuk lain berupa hasil olahan dari telur, yaitu roti.

Dalam pembuatan roti ataupun cake, telur diolah bersama - sama dengan bahan utama tepung, dengan demikian tepung merupakan barang komplemen bagi telur ayam ras. Dengan dasar pemikiran tersebut, pada penelitian ini diduga beras dan tepung terigu merupakan barang komplemen untuk telur ayam ras.

Oleh karena itu, variabel yang diduga mempengaruhi permintaan pasar terhadap telur ayam ras adalah sebagai berikut : 1) harga telur ayam ras, 2) harga telur ayam buras, 3) harga daging broiler, 4) harga daging sapi, 5) harga ikan, 6) harga beras, 7) harga tepung terigu, 8) pendapatan masyarakat Sumatera Barat yang didekati dari PDRB perkapita penduduk, dan 9) jumlah penduduk Propinsi Sumatera Barat.

Dengan asumsi variabel-variabel yang mempengaruhi berhubungan secara linier dengan jumlah permintaan, maka dapat dirumuskan model permintaan pasar telur ayam ras sebagai berikut :

$$
\begin{aligned}
\mathrm{Q}_{\mathrm{t}}= & \mathrm{a}_{\mathrm{0}}-\mathrm{a}_{1} \mathrm{Pq}_{\mathrm{t}}+\mathrm{a}_{2} \mathrm{~Pb}_{\mathrm{t}}+\mathrm{a}_{3} \mathrm{~Pa}_{\mathrm{t}}+\mathrm{a}_{4} \\
& \mathrm{Ps}_{\mathrm{t}}+\mathrm{a}_{5} \mathrm{Pi}_{\mathrm{t}}+\mathrm{a}_{6} \mathrm{Pr}_{\mathrm{t}}+\mathrm{a}_{7} \mathrm{Pr}_{\mathrm{t}}+\mathrm{a}_{8} \\
& \mathrm{Y}_{\mathrm{t}}+\mathrm{a}_{9} \mathrm{~N}_{\mathrm{t}}+e
\end{aligned}
$$

Dimana :

$Q_{t}=$ Jumlah permintaan pasar terhadap telur ayam ras $\mathrm{di}$ Sumbar $(\mathrm{kg} / \mathrm{th})$

$\mathrm{Pq}_{\mathrm{t}}=$ Harga berlaku telur ayam ras (Rp/kg) 
$\mathrm{Pb}_{\mathrm{y}}=$ Harga berlaku telur ayam buras $(\mathrm{Rp} / \mathrm{kg})$

$\mathrm{Pa}_{4}=$ Harga berlaku daging broiler $(\mathrm{Rp} / \mathrm{kg})$

$\mathrm{Ps}_{\mathrm{t}}=$ Harga berlaku daging sapi (Rp/kg)

$\mathrm{Pi}_{4}=$ Harga berlaku ikan $(\mathrm{Rp} / \mathrm{kg})$

$\mathrm{Pr}_{\mathrm{t}}=$ Harga berlaku beras $(\mathrm{Rp} / \mathrm{kg})$

$\mathrm{Pt}_{\mathrm{t}}=$ Harga berlaku tepung terigu $(\mathrm{Rp} / \mathrm{kg})$

$Y_{1}=$ Pendapatan perkapita penduduk (Rp)

$N_{\mathrm{t}}=$ Jumlah penduduk (orang)

$t=$ Periode waktu (tahun).

$a_{0}, a_{1}, a_{2}, a_{3}, a_{4}, a_{5}, a_{6}, a_{7}, a_{8}, a_{9}=$ Koefisien regresi masingmasing variabel yang hendak ditaksir.

$e=$ Error atau variabel-variabel lain yang mempengaruhi variabel bebas yang tidak dimasukkan dalam analisis.

\section{Analisis Data}

Metoda Pendugaan Model

Model permintaan diduga dengan teknik Ordinary Least Square (OLS) dengan menggunakan perangkat lunak SPSS.

\section{Evaluasi Model}

Evaluasi model dilakukan untuk mendapatkan model yang valid yaitu model yang merefleksikan dengan baik realitas perilaku permintaan pasar telur ayam ras di propinsi Sumatera Barat. Evaluasi model dilakukan dengan dua kriteria yaitu kriteria statistik dan ekonometrika Kriteria statistik bertujuan untuk melihat apakah variabel-variabel yang diduga mempengaruhi variasi permintaan telur ayam ras diterima secara statistik. Dalam hal ini ada 3 uji yaitu uji $\mathrm{F}$, untuk melihat pengaruh semua variabel penjelas secara bersama-sama terhadap variabel dependent (jumlah permintaan telur ayam ras), uji $t$ digunakan untuk mengetahui pengaruh masing-masing variabel terhadap permintaan telur ayam ras.

Suatu variabel penjelas di katakan berpengaruh nyata terhadap variabel dependent apabila nilai signifikannya kecil dari taraf nyata yang ditetapkan,. Pada penelitian ini, taraf nyata $(\alpha)$ pengujian ditetapkan pada tingkat $10 \%, 5 \%$ \& $1 \%$ sesuai dengan pendapat Supranto (1990).

Evaluasi dengan kriteria
ekonomertika dilakukan untuk mengevaluasi terpenuhinya asumsi regresi klasik pada model yaitu asumsi bebas dari kasusu multikolinieriti heteroskedastisiti dan autokorelasi. Multikolinieritas dapat dilihat dengan melihat hasil pendugaan model. Menurut Nachrowi dan Usman (2002) multikolinieritas dapat dideteksi jika nilai koefisien determinasi tinggi, tapi hanya sedikit variabel bebas yang berpengaruh secara nyata,

Kasus autokorelasi dideteksi dengan melihat nilai DW. Menurut Firdaus (2004) suatu model dikatakan bebas dari kasusu autokorelasi jika nilai DW-nya berada diantara 1,55 sampai 2,46. Heteroskedastisitas dideteksi dengan mengaktifkan menu scatterplot pada program SPSS, dimana hasil dari scatterplot itu akan menunjukkan hubungan antara nilai $\mathrm{Y}$ yang telah diprediksi dengan residual ( $\mathrm{Y}$ prediksi - $\mathrm{Y}$ sesungguhnya).Dasar pengambilan keputusan adalah, jika ada pola tertentu (bergelombang, melebar) maka terjadi kasus heteroskedastisitas dan jika tidak ada pola yang jelas, titik - titik menyebar diatas dan dibawah angka 0 pada sumbu $Y$, berarti tidak terjadi heteroskedastisitas (Santoso, 2000).

Untuk mendapatkan model yang baik, spesifikasi model akan dilakukan secara iteratif (berulang - ulang) berdasarkan hasil evaluasi model, bisa 
berupa : 1) Mengeluarkan variabelvariabel yang temyata tidak berpengaruh secara nyata, 2) Mentransformasi model

Tahap pengeluaran beberapa variabel penjelas dalam model, dikontrol dengan melihat nilai Adjusted $R$ Square $\left(R^{2}\right.$ yang disesuaikan) dan nilai Standard Error of the Estimatenya. Menurut Santoso (2003) apabila nilai Adjusted R Square semakin baik dan nilai Standard Error of the Estimate semakin menurun, dengan mengeluarkan beberapa variabel penjelas, menunjukkan model tersebut semakin baik.

\section{Penghitungan Nilai Elastisitas}

Untuk model linier, nilai elastisitas harga terhadap permintaan pasar telur ayam ras dapat dicari dengan rumus sebagai berikut :

Elastisitas Permintaan Harga:

$\mathrm{Ep}=\frac{\% \Delta Q x}{\% \Delta P x}=\frac{\partial Q x}{\partial P x} \cdot \frac{P x}{Q x}$

Keterangan :

Ep $=$ Koefisien elastisitas harga barang $\mathrm{X}$

$P x=$ Harga barang $\mathrm{X}$

$Q x=$ Jumlah barang $\mathrm{X}$ yang diminta pada tingkat harga barang $\mathrm{X}$ sebesar Px

Elastisitas Permintaan Terhadap Pendapatan:

$\mathrm{EI}=\frac{\% \Delta Q x}{\% \Delta I x}=\frac{\partial Q x}{\partial L x} \cdot \frac{I x}{Q x}$

Keterangan :

$\mathrm{EI}=$ Koefisien elastisitas barang X

$b x=$ Penghasilan konsumen atau pendapatan konsumen

$Q x=$ Jumlah barang $\mathrm{X}$ yang diminta pada tingkat penghasilan konsumen
Elastisitas Permintaan Silang:

$\mathrm{Ec}=\frac{\% \Delta Q x}{\% \Delta P y}=\frac{\partial Q x}{\partial P y} \cdot \frac{P y}{Q x}$

Keterangan :

$\mathrm{Ec}=$ Koefisien elastisitas antara barang $\mathrm{X}$ dan barang $\mathrm{Y}$

$P y=$ Harga barang $Y$

$Q x=$ Jumlah barang $X$ yang diminta pada tingkat harga barang $\mathrm{Y}$ sebesar Py

Dengan diketahuinya nilai koefisien elastisitas harga dari permintaan, maka akan diketahui sifat permintaan dari telur ayam ras dengan ketentuan sebagai berikut:

Jika koefisien elastisitas harga:

$0<$ Ep $<1$, maka permintaan bersifat inelastis,

Ep $=1$, maka permintaan bersifat uniter,

Ep $>1$, maka permintaan bersifat elastis.

Nilai koefisien elastisitas silang akan menunjukkan sifat hubungan antara komoditi substitusinya:

Jika $E_{c}<0$, berarti sifat telur ayam ras dengan komoditi tersebut saling melengkapi (komplementer),

Jika Ec $>0$, berarti sifat telur ayam ras dengan komoditi tersebut adalah substitusi.

Untuk model log-linier, nilai elastisitas adalah nilai koefisien regresi untuk masing-masing variabel yang bersangkutan. Didapat dari penurunan rumus sebagai berikut :

Elastisitas Harga $=\frac{\partial Q x}{\partial P x} \cdot \frac{P x}{Q x}$

Model dasar log-linier

$Q=a P_{x 1}^{b 1} P_{x 2}^{b 2} P_{x 3}^{b 3} \ldots . P_{x i}^{b i}$

$\begin{aligned} \frac{\partial Q x}{\partial P x} & =\mathrm{b} a P_{x 1}^{b j-1} P_{x 2}^{b 2} P_{x 3}^{b 3} \ldots P_{x i}^{k t} \\ & =\mathrm{b}_{1} \frac{a P x_{1}^{b 1}}{P x_{1}} P_{x 2}^{b 2} P_{x y}^{b 3} \ldots P_{x i}^{b j}\end{aligned}$ 


$$
\begin{aligned}
& =\mathrm{b}_{1} \cdot \frac{Q}{P x_{1}} \\
& =\frac{b_{1} Q}{P x_{1}} \cdot \frac{P x_{1}}{Q} \\
& =b_{1}
\end{aligned}
$$

\section{Hasil Dan Pembahasan}

Estimasi Model Permintaan Pasar Telur Ayam Ras di Sumatera Barat

Berdasarkan model yang telah dibangun pada Bab Metodologi Penelitian, dimana variabel-variabel yang diduga mempengaruhi permintaan pasar telur ayam ras di Propinsi Sumatera Barat adalah harga telur ayam ras, harga telur ayam buras, harga daging broiler, harga daging sapi, harga ikan, harga beras, harga tepung terigu, jumlah penduduk dan pendapatan perkapita. Pendugaan model memberikan hasil sebagai berikut.

Model permintaan yang dibangun ini signifikan pada $\alpha 1 \%$ yang ditunjukkan oleh ANOVA (Analisis of Variance)nya memberikan nilai signifikan dari 0,000 atau $P<0,01$. Hal ini berarti pengaruh variabel-variabel bebas secara bersama - sama signifikan pada taraf nyata $1 \%$. Nilai kocfisien determinasinya 0.953 , artinya variasi permintaan terhadap telur ayam ras dari tahun ke tahun $95,3 \%$ dapat dijelaskan oleh variabel - variabel penjelas yang dimasukkan kedalam model. Hasil uji t menunjukkan dari 9 variabel bebas yang diduga mempengaruhi permintaan pasar terhadap telur ayam ras, hanya ada 4 variabel yang berpengaruh nyata Dari nilai koefisien determinasi yang cukup tinggi tapi hanya sedikit sekali variabel penjelas yang berpengaruh nyata terhadap variabel dependennya, mengindikasikan adanya permasalahan multikolinieritas pada model diatas. Karena pada model tersebut mengindikasikan terjadinya kasus multikolinieritas, bisa disimpulkan nilai parameter yang didapat adalah tidak BLUE, sebagaimana pendapat Nachrowi \& Usman (2002) bila terjadi mutikolinieritas, terkadang taksiran yang didapat akan mempunyai nilai yang tidak sesuai dengan substansi, sehingga dapat menyesatkan interpretasi.

Tabel 1. Hasil Estimasi Model Permintaan Pasar Telur Ayam Ras Tahap I

\begin{tabular}{lccrcrc}
\hline \multicolumn{1}{c}{ Variabel } & $\begin{array}{c}\mathrm{R} \\
\text { Square }\end{array}$ & F-hitung & t-hitung & t-sign & $\begin{array}{c}\text { Koef } \\
\text { Regresi }\end{array}$ & $\begin{array}{r}\text { Durbin- } \\
\text { Watson }\end{array}$ \\
\hline Konstanta & 0,953 & 22,543 & 1,410 &, 189 & 19781260 & 2,222 \\
Hrg Tlr A Ras & & $(0,000)$ & $-1,077$ &, $307 \mathrm{NS}$ & $-1200,25$ & \\
Hrg Tlr A Buras & & & $-1,614$ &, $138 \mathrm{NS}$ & $-790,54$ & \\
Hrg Dg Broiler & & & $-6,896$ &, $000^{*}$ & $-3457,44$ & \\
Hrg Dgg Sapi & & & 3,176 &, $010^{*}$ & 2493,02 & \\
Hrg Ikan & & & 2,576 &, $028^{* *}$ & 3573,55 & \\
Hrg Beras & & &,- 455 &, $659 \mathrm{NS}$ & $-1587,14$ & \\
Hrg Tp Terigu & & & $-2,521$ &, $030 * *$ & $-7153,39$ & \\
Jml Penduduk & & &,- 709 &, $495 \mathrm{NS}$ & $-2,55$ & \\
Pendapatan & &,- 352 &, $732 \mathrm{NS}$ & $-1,09$ & \\
\hline
\end{tabular}

Catatan : Angka dalam kurung adalah nilai Signifikan F-hitung

Keterangan : * = Signifikan pada $\alpha 1 \%$

** - Signifikan pada a $5 \%$
$* * *=$ Signifikan pada $\alpha .10 \%$

NS - Non Signifikan 
Oleh karena itu pada model diatas tidak dilakukan lagi uji lebih lanjut untuk mendeteksi apakah pada model terjadi kasus ekonometrika lainnya (yaitu kasus autokorelasi dan heteroskedastisitas).

Untuk itu model diperbaiki dengan mengeluarkan variabelvariabel yang secara statistik tidak berpengaruh nyata terhadap permintaan pasar telur ayam ras. Sebagaimana terlihat pada Tabel 1 ada 5 variabel yang tidak berpengaruh nyata yaitu (1) harga telur ayam ras itu sendiri, (2) harga telur ayam buras, (3) harga beras, (4) jumlah penduduk dan (5) pendapatan masyarakat.

Namun tidak ke 5 variabel tersebut langsung dikeluarkan dari model, dua variabel yang pada model pertama tidak berpengaruh nyata yaitu harga telur ayam ras itu sendiri dan tingkat pendapatan masyarakat tetap dipertahankan, dengan pertimbangan karena secara teori variabel harga barang itu sendiri dan pendapatan masyarakat sangat mempengaruhi permintaan terhadap suatu komoditas. Dengan mengeluarkan beberapa variabel diharapkan akan ada perubahan hasil. Hasil pendugaan model yang sudah diperbaiki ditampilkan pada Tabel 2 .

Dengan dikeluarkannya beberapa variabel yang tidak signifikan, terjadi perubahan hasil. Untuk variabel harga telur ayam ras yang sebelumnya tidak signifikan menjadi, signifikan pada a $10 \%$. Variabel tingkat pendapatan masyarakat tetap tidak signifikan, $(\mathrm{P}>0,10)$.

Pada model diatas terjadi kasus autokorelasi yang ditunjukkan oleh nilai DW diatas 2.46 yaitu sebesar 2.762. Menurut Yuwono( 2005), kasus autokorelasi sering terdapat pada data time series karena banyak data statistik yang oleh karena beberapa sebab diinterpolasi atau melakukan proses penghalusan, akibatnya gangguan estimasinya menjadi berkorelasi antara satu dengan yang lainnya.

Untuk mengatasi masalah autokorelasi maka dilakukan transformasi dengan logaritma, karena menurut Nachrowi dan Usman (2002) secara umum autokorelasi sulit untuk diatasi, namun transformasi logaritma dapat mengurangi korelasi.

Tabel 2. Hasil Estimasi Model Permintaan Pasar Telur Ayam Ras Tahap II

\begin{tabular}{|c|c|c|c|c|c|c|}
\hline Variabel & $\begin{array}{c}\text { R } \\
\text { Square }\end{array}$ & $\begin{array}{c}\text { F- } \\
\text { hitung }\end{array}$ & t-hitung & t-sign & $\begin{array}{c}\text { Koef } \\
\text { Regresi }\end{array}$ & $\begin{array}{l}\text { Durbin- } \\
\text { Watson }\end{array}$ \\
\hline Konstanta & 0,937 & 32,266 & 12,342 &, 000 & 10649466 & 2,762 \\
\hline Hrg Tlr A Ras & & $(0,000)$ & $-1,884$ &, $082^{* * 4}$ & $-1921,03$ & \\
\hline Hrg Dg Broiler & & & $-6,694$ &, $000^{*}$ & $-3270,97$ & \\
\hline Hrg Dgg Sapi & & & 2,939 &, $012 * *$ & 1822,57 & \\
\hline Hrg Ikan & & & 2,231 & $.044 * *$ & 2723,11 & \\
\hline Hrg Tp Terigu & & & $-3,279$ &, $006^{*}$ & $-7871,10$ & \\
\hline Pendapatan & & &, 480 & , $640 \mathrm{NS}$ & 1,16 & \\
\hline
\end{tabular}

Catatan : Angka dalam kurung adalah nilai Signifikan F-hitung

Keterangan : * = Signifikan pada $\alpha$. $1 \%$

** = Signifikan pada a. $\$ \%$

$$
* * *=\text { Signifikan pada } \alpha \quad 10 \%
$$$$
\text { NS - Non Signifikan }
$$ 
Untuk itu dicoba merumuskan model baru untuk fungsi permintaan telur ayam ras berupa model logaritma ganda seperti :

$\mathrm{Y}=e^{c} X_{1}^{h 1} X_{2}^{b 2} X_{3}^{b 3} \ldots X_{1}^{h b}$

(Yuwono, 2005).

Model diatas dapat dilinierkan, sehingga persamaanya menjadi :

$\log Y=a+b_{1} \log x_{1}+b_{2} \log x_{2}+b_{3}$

$$
\log x_{3}+\ldots b_{i} \log x_{i}
$$

Model ini relatif lebih baik dari model sebelumnya, nilai DW yang 1.950 mengindikasikan tidak adanya kasus autokorelasi pada model ini. Model ini juga bebas dari kasus heteroskedastisitas ditunjukkan oleh tidak adanya pola yang jelas pada diagram scaterplot dimana titik-titik menyebar diatas dan dibawah angka nol pada sumbu Y (Santoso, 2000).

Karena variabel pendapatan tidak signifikan hasilnya model dicoba diperbaiki dengan mengganti variabel pendapatan yang awalnya didekati dari PDRB perkapita dengan PDRB riil, agar peningkatan pendapatan mencerminkan peningkatan daya beli masyarakat, yaitu nilai PDRB yang sudah di deflasi dengan indeks berantai yang menggunakan tahun 2000 sebagai tahun dasar. Didapat hasil sebagaimana terlihat pada Tabel 3.

Tabel 3. Hasil Estimasi Model Logaritma Permintaan Pasar Telur Ayam Ras Tahap I

\begin{tabular}{lccrlrl}
\hline \multicolumn{1}{c}{ Variabel } & $\begin{array}{c}\mathrm{R} \\
\text { Square }\end{array}$ & $\begin{array}{c}\mathrm{F}- \\
\text { hitung }\end{array}$ & t-hitung & t-sign & $\begin{array}{c}\text { Koef } \\
\text { Regresi }\end{array}$ & $\begin{array}{r}\text { Durbin- } \\
\text { Watson }\end{array}$ \\
\hline Konstanta & 0,771 & 9,405 & 3,932 &, 002 & 4,832 & 1,950 \\
Hrg Tlr A Ras & & $(0,000)$ & $-2,130$ &, $051^{* * *}$ &,- 851 & \\
Hrg Dg Broiler & & & $-4,944$ &, $000^{*}$ & 3,078 & \\
Hrg Dgg Sapi & & & 3,390 &, $004^{*}$ & $-1,867$ & \\
Hrg Tpg Terigu & & & $-1,483$ &, $160 \mathrm{NS}$ &,- 539 & \\
Pendapatan & & &, 314 &, $759 \mathrm{NS}$ &, 198 & \\
\hline
\end{tabular}

Catatan : Angka dalam kurung adalah Signifikan F-hitung

Keterangan :* - Signifikan pada $\alpha 1 \% \quad * *=$ Signifikan pada $\alpha 10 \%$

$* *$ = Signifikan pada $\alpha 5 \% \quad$ NS = Non Signifikan

Tabel 4. Hasil Estimasi Model Logaritma Permintaan Pasar Telur Ayam Ras Tahap II

\begin{tabular}{lccrcrc}
\hline \multicolumn{1}{c}{ Variabel } & $\begin{array}{c}\mathrm{R} \\
\text { Square }\end{array}$ & $\begin{array}{c}\text { F- } \\
\text { hitung }\end{array}$ & t-hitung & t-sign & $\begin{array}{r}\text { Koef } \\
\text { Regresi }\end{array}$ & $\begin{array}{c}\text { Durbin- } \\
\text { Watson }\end{array}$ \\
\hline Konstanta & 0,773 & 9,509 & 1,872 &, 082 & 6,911 & 1,966 \\
Hrg Tir A Ras & & $(0,000)$ & $-2,558$ &, $023 * *$ &,- 937 & \\
Hrg Dg Broiler & & & $-4,384$ &, $001 *$ & $-1,761$ & \\
Hrg Dgg Sapi & & & 5,474 &, $000^{*}$ & 3,373 & \\
Hrg Tpg Terigu & & & $-1,434$ &, $174 \mathrm{NS}$ &,- 500 & \\
PDRB Riil & & &,- 468 &, $647 \mathrm{NS}$ &,- 311 & \\
\hline
\end{tabular}

Catatan : Angka dalam kurung adalah Signifikan F-hitung

Keterangan : * = Signifikan pada $\alpha 1 \%$

$* *$ = Sigaifikan pada $\alpha .5 \%$

*** = Signifikan pada a $10 \%$

NS - Non Signifikan 
Dari besarnya nilai signifikan untuk variabel pendapatan, dapat disimpulkan bahwa peningkatan pendapatan masyarakat tidak memberikan pengaruh pada peningkatan permintaan terhadap telur ayam ras di Sumatera Barat.

Dengan bebasnya model logaritma dari kasus multikolinieriti, autokorelasi dan heteroskedastisitas, disimpulkan hasil estimasi model logaritma tahap II menghasilkan nilai parameter yang BLUE.

Dengan demikian, dapat disimpulkan variabel-variabel yang berpengaruh pada permintaan pasar telur ayam ras di propinsi Sumatera Barat adalah : 1) harga telur ayam ras itu sendiri, 2) harga daging broiler, dan 3) harga daging sapi, sedangkan variabel pendapatan riil penduduk dan tepung terigu tidak berpengaruh terhadap permintaan pasar telur ayam ras.

Dari hasil estimasi model permintaan pasar telur ayam ras terpilih didapat model fungsi permintaan pasar terhadap telur ayam ras sebagai berikut:

$\log Q_{t}=6,911-0,937 \log P q_{t}-1,761$ $\log \mathrm{Pa}_{4}+3,373 \log \mathrm{Ps}_{s_{1}}-0,500$ $\log \mathrm{Pt}_{4}=0,311 \log \mathrm{Y}_{\mathrm{t}}$

\section{Pengaruh dari Variabel Harga Telur Ayam Ras}

Dari nilai koefisien regresi yang negatif, menunjukkan bahwa variabel harga telur ayam ras berhubungan secara negatif, sesuai dengan kaidah hukum permintaan apabila harga telur ayam ras naik, permintaan terhadap telur ayam ras akan turun.

\section{Pengaruh Variabel-variabel Lain}

Dari empat jenis komoditi yang diduga merupakan barang substitusi bagi telur ayam ras yaitu telur ayam buras, daging broiler, daging sapi, dan ikan, ternyata hanya ada 2 komoditas yang berpengaruh terhadap permintaan telur ayam ras yaitu daging broiler dan daging sapi dimana hubungan antara daging broiler dan telur ayam ras adalah bersifat barang komplemen. Hal ini ditunjukkan oleh nilai koefisien regresinya yang bertanda negatif. Sesuai dengan pendapat Sukimo (1999) untuk barang-barang yang bersifat komplemen jumlah barang yang diminta berubah kearah yang bertentangan dengan perubahan harga barang lain.

Kalau dilihat dari manfaatnya, dimana telur ayam ras dan daging broiler sama-sama merupakan sumber protein hewani, sehingga bisa dikatakan bahwa hubungan antara telur ayam ras dan daging broiler adalah merupakan barang substitusi. Tetapi dari hasil pendugaan model (fenomena empiris) didapat antara telur ayam ras dan daging broiler bersifat komplemen. Kondisi seperti ini juga didapatkan oleh Ilham, Hastuti dan Kariyasa (2002) dimana ada beberapa barang yang secara teoritis merupakan barang substitusi tapi dari penelitian dengan data empiris, didapatkan hubungan adalah komplemen yaitu : telur ayam ras dan daging broiler merupakan produk komplemen bagi daging sapi. Menurut Ilham, Hastuti dan Kariyasa (2002) peran telur ayam sebagai produk komplemen bagi daging mengindikasikan bahwa perilaku konsumen dalam mengkonsumsi bukan atas dasar rasa tapi adanya variasi dalam penyajian, maka wajar beberapa produk peternakan saling berkomplemen.

Daging sapi merupakan barang substitusi untuk telur ayam ras. Dilihat dari peranannya yang sama-sama sumber protein hewani, maka kondisi ini sesuai dengan harapan 
Walaupun tepung terigu secara statistik tidak berpengaruh, tapi tanda koefisiennya sesuai dengan teori ekonomi yaitu tepung terigu merupakan barang komplemen untuk telur ayam ras. Hal ini menyatakan telur ayam ras tidak hanya dikonsumsi sebagai lauk dalam menu sehari-hari, tetapi juga dikonsumsi dalam bentuk yang sudah diolah menjadi makanan tambahan.

Pendapatan penduduk yang tidak berpengaruh berarti tingkat konsumsi untuk telur ayam ras secara kuantitatif sudah pada tingkat yang tinggi, sesuai teori permintaan untuk komoditi pangan, kebutuhan akan bahan makanan mempunyai titik jenuh, bila secara kuantitas kebutuhan makanan seseorang sudah terpenuhi,jika terjadi peningkatan pada pendapatan, ia akan beralih ke pangan yang kualitasnya lebih tinggi atau beralih pada kebutuhan bukan pangan (BPS, 2005).

\section{Nilai Elastisitas Harga Sendiri}

Elastisitas harga sendiri untuk telur ayam ras sebesar $-0,937$, berarti elastisitas harga bersifat inelastis artinya permintaan terhadap telur ayam ras tidak terlalu terpengaruh oleh perubahan harga, berarti telur ayam ras sudah merupakan barang kebutuhan pokok komoditi utama sumber protein hewani, ini bisa dipahami karena harganya yang jauh relatif lebih murah dibandingkan dengan sumber protein hewani lainnya. Disamping itu, elastisitas permintaan bersifat inelastis karena disebabkan komoditi ras tak mempunyai barang substitusi yang dekat.

\section{Nilai Elastisitas Silang}

Untuk barang substitusi dalam hal ini daging sapi, nilai elastisitas silang antara daging sapi dan telur ayam ras sebesar 3,373 , berarti elastisitas silang bersifat elastis artinya perubahan harga daging sapi sangat besar pengaruhnya terhadap permintaan telur ayam ras. Jika harga daging sapi naik $1 \%$, permintaan terhadap telur ayam ras akan naik sebesar $3,373 \%$, begitu pula sebalikanya.

Untuk daging broiler, yang merupakan barang komplemen bagi telur ayam ras, apabila harga daging broiler meningkat $1 \%$ maka permintaan terhadap telur ayam ras akan mengalami penurunan sebesar $1,761 \%$.

\section{Nilat Elastisitas Pendapatan}

Apabila dilihat hubungan permintaan telur ayam ras dengan pendapatan riil penduduk Sumatera Barat, yang dilihat dari koefisien elastisitasnya adalah kurang dari satu $(-0,311)$, telur ayam ras dikategorikan sebagai kebutuhan pokok artinya permintaan akan telur ayam ras tidak akan berubah banyak dalam hubungan dengan perubahan pendapatan maupun harganya. Dilihat dari nilai koefisien pendapatan yang bertanda negatif, maka telur ayam ras dikategorikan barang inferior, artinya permintaan akan telur ayam ras akan berkurang apabila pendapatan meningkat.

\section{Kesimpulan}

Permintaan pasar terhadap telur ayam ras di Propinsi Sumatera Barat dipengaruhi oleh variabel-variabel : harga felur ayam ras itu sendiri, harga daging broiler, dan harga daging sapi. Peningkatan jumlah penduduk dan pendapatan, tidak berpengaruh terhadap permintaan pasar telur ayam ras di Propinsi Sumatera Barat. Barang substitusi terhadap telur ayam ras di 
pasar Propinsi Sumatera Barat adalah

Permintaan pasar tehadap telur ayam ras di Propinsi Sumatera Barat, responsif terhadap perubahan harga telur ayam ras itu sendiri, dimana nilai elastisitas harganya $-0,937$. Permintaan pasar tehadap telur ayam ras di Propinsi Sumatera Barat, sangat responsif terhadap perubahan harga daging broiler dan daging sapi dengan nilai elastisitas silang berturut-turut 1,761 dan 3,373 .

\section{DAFTAR PUSTAKA}

Biro Pusat Statistik. 2004. Sumatera Barat Dalam Angka. Biro Pusat Statistik Sumatera Barat. Padang

Firdaus, M. 2004. Ekonometrika Suatu Pendekatan Aplikatif. PT. Bina Aksara. Jakarta.

Illam, N, S. Hastuti, dan J. K. Kariyasa. 2002. Pendugaan Parameter dan Elastisitas Penawaran dan Permintaan daging sapi.

Beberapa Jenis Daging di Indonesia. Jurnal Agroekonomi volume 20 nomor 2 oktober 2002

Mulyono, S. 2000. Peramalan Bisnis Dan Ekonometrika. Edisi Pertama. BPFE-Yogyakarta. Yogyakarta.

Nachrowi, N. D, dan H. Usman. 2002. Penggunaan Teknik Ekonometri. Edisi Pertama. PT. Raja Grafindo Persada. Jakarta.

Santoso, S. 2000. SPSS Versi 10 Mengolah Data Statistik Secara Profesional. PT.Elex Media Komputindo. Kelompok Gramedia. Jakarta.

Supranto, J. 1990. Statistik Teori dan Aplikasi. Edisi Ketiga. Jilid 1. Erlangga. Jakarta.

Yuwono, P. 2005. Pengantar Ekonometri. Edisi Pertama. Andi, Yogyakarta.

Alamat korespondensi: Jum'atri Yusri, S.Pt, M.Si

Jurusan Produksi Ternak Fakultas Peternakan

Universitas Andalas, Kampus Limau Manis, Padang

HP : 081374591155

Diterima: 7 Januari 2007, Disetujui: 20 Februari 2007 